\title{
Exchange Rate Behavior of Plantation Subsector Farmers in North Kolaka Regency
}

Salahuddin Salahuddin ${ }^{1}$, Laode Muh. Munadi*2, Muhammad Amrullah Pagala², Rina Astarika ${ }^{3}$

${ }^{1}$ Agricultural Faculty, Halu Oleo University, Kampus Hijau Bumi Tridharma, Anduonohu,

Kendari, Southeast Sulawesi, Indonesia

${ }^{2}$ Faculty of Animal Husbandry, Halu Oleo University, Kampus Hijau Bumi Tridharma, Anduonohu,

Kendari, Southeast Sulawesi, Indonesia.

${ }^{3}$ Terbuka University, UPBJJ Yogyakarta, Indonesia.

\section{ABSTRACT}

Article Info

Volume 8, Issue 4

Page Number : 90-97

Publication Issue :

July-August-2021

\section{Article History}

Accepted : 01 July 2021

Published: 07 July2021
The implementation of the research on the behavior of farmers exchange rate subsector plantations in North Kolaka District, conducted in the sub-district area that qualifies as a sample area in the researcher's perspective aims to see the exchange rate behavior of plantation subsector farmers in north Kolaka district, conducted in January-March 2021. The calculation of Farmer Exchange Rate is obtained from the comparison of the price index received by farmers against the price index paid by farmers using the survey method with the number of 340 respondents spread in North Kolaka Regency. The results showed that the behavior of the price received by farmers $110.23 \%$, The Behavior of Prices Paid by Farmers 95.22\%, and the exchange rate of farmers in the subsector of plantation crops in North Kolaka District in 2019-2020 $115.81 \%$.

Keywords: Farmer Exchange Rate, Plantation, North Kolaka

\section{INTRODUCTION}

Farmer Exchange Rate (NTP) is one measure in determining welfare. This study aims to determine the development of NTP Padi position and Exchange Rate of farmers of other food commodities in Indonesia, know the calculation of Rice NTP and analyze the factors that affect NTP [1].

Farming activities are determined by the protection and welfare of farmers in farming activities [2]. Farmer Exchange Rate (NTP) is one of the tools to measure the level of welfare of farmers [3]. The increasing exchange rate of farmers will affect the sustainability of farmers to conduct farming activities in order to produce agricultural products. Indicators of farmers' welfare are the amount of income and the balance with spending [4]. In this regard, one of the measuring instruments that are often used is the exchange rate of farmers (NTP) [5]. NTP calculation is obtained from the comparison of the price index received by farmers against the price index paid by farmers [5]. The farmer's exchange rate describes the exchange rate/purchasing power of farmers to 
products purchased/paid by farmers which includes consumption and input of purchased production [6]. The higher the exchange rate of farmers, the better the purchasing power of farmers to the product consumption and input production, and means relatively more prosperous [7].

NTP is the only option for agricultural development observers in assessing the level of welfare of farmers. Thus, NTP is one of the relative indicators of farmers' welfare level [8]. The higher the NTP, the relatively more prosperous the level of life of farmers. Basically the general balance theory, shows that NTP can be used as a gauge of the level of welfare of farmers. Conceptually the direction of NTP (increasing or decreasing) is the resultant of the direction of each constituent component, namely the component of acceptance that has a positive direction towards the welfare of farmers and the component of payments that have a negative direction towards welfare [9]. If the rate of receiving component is higher than the payment rate then the farmer's exchange rate will increase, vice versa. NTP up or down movement represents the ups and downs of farmers' welfare levels [10].

Farmer Exchange Rate (NTP) measures the exchange rate of agricultural commodities produced by farmers to products purchased by farmers for consumption and purposes in producing farming. The farmer exchange rate (NTP Padi) is defined as the ratio between the price received by farmers $(\mathrm{HT})$ and the price paid by farmers $(\mathrm{HB})$ or NTP $=\mathrm{HT} / \mathrm{HB}$ [11]. The index is a weighted value against quantity in a given base year. The movement of the exchange rate will be determined by the determination of the base year because the difference in the base year will result in the growth of different indices [12].

The exchange rate of food farmers is an indicator of farmers' welfare. In measuring the level of welfare of farmers, the instruments used are farmer exchange rates (NTP). The increase in NTP indicates an increase in farmers' welfare, and vice versa. The price received by farmers is the weighted price of each agricultural commodity produced/sold by farmers [13]. The weighing used is the production value sold by farmers of each commodity [14]. Agricultural commodity prices are the average price received by farmers or "Farm Gate". The increase in food prices today, especially rice, has to do with the value that farmers have to pay which is higher than the value received by farmers [15]. Therefore, we must deal with it wisely, realistically, positively and optimistically so that the risks ahead can be minimized to a minimum, especially in the long term risk that certainly threatens the welfare of farmers and the economic community [16]. Farmers referred to in the ntp concept of BPS are farmers who strive in the sub-sectors of food crops, horticulture, people's plantations, farmers, as well as farmers of aquaculture and fishermen [17]. Farmers of sub-sectors of food crops include farmers who strive on rice farming and crops; horticultural sub-sector farmers include vegetable and fruit farmers; people's plantation farmers consist of farming commodities people's trade; farmers engaged in the business of large livestock, small livestock, poultry, and livestock products; as well as fishing farmers who include fish farming farmers and fishing fishermen [18].

NTP relates to the purchasing power of farmers in terms of financing their household needs. If farmers' income is greater than the increase in agricultural production price and has an impact on their purchasing power, this will identify that farmers' ability to be better or increase their income [19]. The price paid by farmers is the weighted price of the price/cost of food consumption, non-food consumption and production costs and the addition of capital goods from goods consumed or purchased by farmers [20]. Self-produced commodities are not included in the calculation of the price paid by 
farmers. The price in question is the retail price of goods and services in the rural market [21].

Farmer Exchange Rate in its development has been developed with national and regional analysis units, so that it obtained excellence because it is a national and regional macro indicator of the level of regional farmer welfare [22]. Through NTP and its components can be known relative comparison of Farmer Exchange Rate or Agricultural Commodity Exchange Rate between regions (provinces). Conceptually the direction of NTP (farmer welfare) is the resultant of the direction of each Component Exchange Rate Forming, namely the exchange rate component of farmers' acceptance that has a positive direction towards the welfare of farmers and the exchange rate of the payment component that has a negative direction to the welfare of farmers [23]. If the exchange rate of the receiving component is higher than the rate of exchange rate of the component then the Farmer Exchange Rate (NTP) will increase, and vice versa [24].

Thus, in the Calculation of Farmers Exchange Rate is an aggregation of the constituent exchange rate. NTP is an aggregation of NTP sub-sectors (food crop subsectors, horticultural sub-sectors, plantation subsectors, livestock sub-sectors, and fishery sub-sectors) [25]. NTP sub-sector of food crops is composed of NTP components of rice and NTP palawija group, and NTP palawija is composed of NTP commodities palawija (corn, and soybeans) [26]. Researchers aim to look at the exchange rate behavior of plantation subsector farmers in north Kolaka district.

\section{METHODS AND MATERIAL}

Research method is a method or technique used in carrying out and completing research on farmer exchange rate behavior, which includes the location and time of activities, data collection methods, and data analysis methods. The research was conducted in
January-March 2021 in North Kolaka Regency by collecting primary data from interviews of 340 respondents. The method of data analysis used in farmer exchange rate research is NTP analysis where NTP Analysis is used to measure the exchange rate of agricultural commodities produced by farmers to products purchased by farmers for consumption and production of farming. In this study, NTP value is projected with BPS approach, which is the ratio between the price received (IT) and the price paid by farmers (IB). Mathematically the NTP equation is as follows:

\section{$N T P=I T / I B$}

\section{Description;}

$\mathrm{NTP}=$ Farmer exchange rate

IT $=$ Price index received by farmers

$\mathrm{IB}=$ Index of prices paid by farmers

The index is a weighted value against quantity in a given base year. The movement of the exchange rate will be determined by the determination of the base year because the difference in the base year will result in the rapid development of different indices. The Index Formulation used is Laspeyres Index:

$$
I=\frac{\sum Q_{0} * P_{i}}{\sum Q_{0} * P_{0}}
$$

\section{Description:}

I = Laspeyres Index

Qo = Quantity in a given base year (year 0 )

$\mathrm{Po}=$ Price in a given base year (year 0

$\mathrm{Pi}=$ Price in the year $\mathrm{i}$

\section{III.RESULTS AND DISCUSSION}

Development activities are basically aimed at improving the welfare of the community. As an agrarian country with a large number of people working in agricultural activities, it is appropriate for national development and moreover agricultural 
development to pay attention to the welfare of farmers. One of the fields of agricultural business is the plantation sector and for that attention to the welfare of planters farmers also need attention.

Indicators / measuring instruments that can be used to assess the level of welfare of farmers is the Farmer Exchange Rate (NTP). The amount of marginal coefficient of increase and elasticity of each constituent component against NTP. The amount of marginal value and elasticity of NTP describes the magnitude of the influence of price changes on NTP. The development of farmers' exchange rates, the behavior of prices received by farmers, and the behavior of prices paid by farmers, especially in subsectors of plantation crops. Farmer Exchange Rate (NTP) is defined as the ratio between the price received by farmers (HT) and the price paid by farmers (HB). HT and $\mathrm{HB}$ are the weighted prices of the forming prices (commodity prices and prices of consumer goods and production facilities) by the weighting of the amount of production sold and the value purchased by farmers. Thus the establishment of NTP is a complex mechanism related to the aspects of farmers' income and aspects of farmer expenditure (consumption). The diversity of each region in terms of agricultural resources and production, commodities produced and technology, as well as diversity in consumption patterns will lead to the diversity of ntp price formation and diversity.

Knowledge of the behavior of the exchange rate of garden farmers is inseparable from the constituent factors, both the constituent components of HT (the price received) and the constituent components of $\mathrm{HB}$ (the price paid), and the factors that affect the exchange rate of farmers of the garden will be very useful for the improvement of policy and plantation development programs in the future. The establishment of NTP index as an indicator of farmers' welfare has been carried out by BPS in 1987 and continuous improvement is made. At first the definition of "farmer" was limited to farmers who tried on the land, so the scope of farmers was only farmers of food crops and plantation crops of the people. Since 2008, the Central Bureau of Statistics compiled NTP using the base year 2007=100 for Subsectors of Food Crops, Horticultural Crops, People's Plantation Crops, Livestock, and Fisheries. Furthermore, starting december 2013 using the base year 2012=100, with the expansion of the Subsector of Fisheries divided into two, namely Subsector of Catch Fisheries (NTN) and Subsector of Cultivation (NTPi). The data was collected through agricultural sector producer price survey and rural consumer price survey in 10 districts in Southeast Sulawesi Province. For information in this study, the analysis of ntp value of North Kolaka Regency is limited to NTP subsector of plantation crops

\section{A. Farmer Acceptable Price Behavior (IHP)}

The price received by farmers is the weighted price of each agricultural commodity produced/sold by farmers. The weighing used is the production value sold by farmers of each commodity. Agricultural commodity prices are the average price received by farmers. Overview of the prices received by farmers in North Kolaka Regency is presented in Table 1.

Table 1. Price Received by Plantation Farmers in North Kolaka Regency in 2019-2020

\begin{tabular}{|l|r|r|r|c|}
\hline \multirow{2}{*}{$\begin{array}{c}\text { Plantatio } \\
\text { n Plants }\end{array}$} & \multicolumn{2}{|c|}{ Acceptance } & \multirow{2}{*}{$\begin{array}{c}\text { Growt } \\
\text { (Rp/Ha/Harvest Season) }\end{array}$} & $\begin{array}{c}\text { IHP } \\
\text { h (\%) }\end{array}$ \\
\cline { 2 - 3 } & $\mathbf{2 0 1 9}$ & \multicolumn{1}{c|}{$\mathbf{2 0 2 0}$} & & \\
\hline Cocoa & $9,419,008$ & $10,742,479$ & 14.05 & 114.05 \\
\hline Coconut & $1,830,000$ & $2,019,938$ & 10.38 & 110.38 \\
\hline Clove & $24,442,105$ & $25,973,684$ & 6.27 & 106.27 \\
\hline Total & $\mathbf{3 5 , 6 9 1 , 1 1 4}$ & $\mathbf{3 8 , 7 3 6 , 1 0 1}$ & $\mathbf{3 0 . 7 0}$ & $\mathbf{3 3 0 . 7 0}$ \\
\hline & $\mathbf{1 1 , 8 9 7 , 0 3 7 .}$ & $\mathbf{1 2 , 9 1 2 , 0 3 3 .}$ & & \\
Average & $\mathbf{8 4}$ & $\mathbf{6 8}$ & 10.23 & 110.23 \\
\hline
\end{tabular}

Southeast Sulawesi province, especially North Kolaka Regency, that cocoa commodity is the main leading commodity and most prominent compared to other 
types of plantation crops. Although classified as a leading commodity, in general the people's cocoa farming still has some shortcomings and needs to be improved. The shortcomings are related to various aspects, ranging from cultivation, maintenance, harvest / post-harvest, processing, to marketing. But with the potential, this farm has the opportunity to be improved both technically and in terms of institutional arrangements. Cocoa farming is seen as the total net income obtained has increased in the period 2019-2020, an increase due to the high productivity achieved. However, one of the factors of cocoa fruit driving pest (PBK) that until now has not been overcome by farmers and pests of pig animals and apes that damage cocoa fruit and even damage crops. Cocoa farming revenue as contained in Table 8.1, increased, this is due to the component production costs that increased from Rp. 9,419,008 million/ha/season - Rp. 10,742,479 million/ha/season). Similarly, coconut and clove communiqué tends to increase with an average of 10.23\%-110.23\%. Meanwhile, the price index received by farmers in the plantation subsector is presented in Table 2. Table 2 shows that the price received by farmers in the plantation subsector in North Kolaka Regency in general decreased negatively by $4.78 \%$, with the value of the price index received by farmers at $95.22 \%$. The phenomenon will certainly in the long run reduce the increase in the amount of farmers' income in the plantation subsector in North Kolaka Regency.

Table 2. Price Paid by Farmers in Subsector of Plantation Crops in North Kolaka Regency in 20192020.

\begin{tabular}{|c|c|c|c|c|}
\hline \multirow{2}{*}{$\begin{array}{c}\text { Plantation } \\
\text { Plants }\end{array}$} & \multicolumn{2}{|c|}{ Expense } & \multirow{2}{*}{$\begin{array}{l}\text { Growt } \\
\mathrm{h}(\%)\end{array}$} & \multirow{2}{*}{$\begin{array}{l}\text { IHB } \\
\text { (\%) }\end{array}$} \\
\hline & 2019 & 2020 & & \\
\hline \multicolumn{5}{|c|}{ Household Consumption (Per Capita): } \\
\hline Food Group & 459,331 & 542,439 & 18.09 & 118.0 \\
\hline $\begin{array}{l}\text { Non-Food } \\
\text { Group }\end{array}$ & 426,667 & 459,184 & 7.62 & $\begin{array}{c}107.6 \\
2\end{array}$ \\
\hline Total & 885,998 & $1,001,623$ & 25.71 & 225.7 \\
\hline
\end{tabular}

\begin{tabular}{|l|c|c|c|c|} 
& & & & 1 \\
\hline $\begin{array}{l}\text { Cost of Production and Addition of Capital Goods } \\
\text { (Rp/Ha/Harvest: }\end{array}$ \\
\hline Cocoa & $3,569,917$ & $3,168,182$ & $(11.25)$ & 88.75 \\
\hline Coconut & $3,747,500$ & $3,475,000$ & $(7.27)$ & 92.73 \\
\hline Clove & $2,805,263$ & $2,522,368$ & $(10.08)$ & 89.92 \\
\hline Total & $10,122,681$ & $\mathbf{9 , 1 6 5 , 5 5 0}$ & $(\mathbf{2 8 . 6 1 )})$ & $\begin{array}{c}\mathbf{2 7 1 . 3} \\
\mathbf{9}\end{array}$ \\
\hline Average & $\mathbf{2 , 2 0 1 , 7 3 6}$ & $\mathbf{2 , 0 3 3 , 4 3 5}$ & $\mathbf{( 0 . 5 8 )}$ & $\mathbf{9 9 . 4 2}$ \\
\hline $\begin{array}{l}\text { Consumption Costs and Production Costs Addition of } \\
\text { Capital Goods }\end{array}$ & $4,455,915$ & $4,169,805$ & $(6.42)$ & 93.58 \\
\hline Cocoa & $4,633,498$ & $4,476,623$ & $(3.39)$ & 96.61 \\
\hline Coconut & $3,691,261$ & $3,523,991$ & $(4.53)$ & 95.47 \\
\hline Clove & $\mathbf{1 2 , 7 8 0 , 6 7 5}$ & $\mathbf{1 2 , 1 7 0 , 4 1 9}$ & $(\mathbf{1 4 . 3 4 )}$ & $\mathbf{2 8 5 . 6}$ \\
\hline Total & $\mathbf{4 , 2 6 0 , 2 2 4 .}$ & $\mathbf{4 , 0 5 6 , 8 0 6 .}$ & $\mathbf{( 4 . 7 8 )}$ & $\mathbf{9 5 . 2 2}$ \\
\hline Average & $\mathbf{8 4}$ & $\mathbf{4 1}$ & & \\
\hline
\end{tabular}

\section{B. Farmer's Price Behavior}

The price paid by farmers is the weighted price of the price/cost of food consumption, non-food consumption and production costs and the addition of capital goods from goods consumed or purchased by farmers. Self-produced commodities are not included in the calculation of the price paid by farmers. The price in question is the retail price of goods and services in the rural market. An overview of the prices paid by farmers in North Kolaka Regency is presented in Table 3.

Table 3. Price Paid by Farmers in Subsector of Plantation Crops in North Kolaka Regency in 2019-

2020

\begin{tabular}{|l|c|c|c|c|}
\hline \multirow{2}{*}{$\begin{array}{c}\text { Plantatio } \\
\text { n Plants }\end{array}$} & \multicolumn{2}{|c|}{ Expense } & Growt & IHB \\
h (\%) & (\%) \\
\hline Household Consumption (Per Capita): \\
\hline $\begin{array}{l}\text { Food } \\
\text { Group }\end{array}$ & 459,331 & 542,439 & 18.09 & $\begin{array}{c}118.0 \\
9\end{array}$ \\
\hline $\begin{array}{l}\text { Non- } \\
\text { Food } \\
\text { Group }\end{array}$ & 426,667 & 459,184 & 7.62 & $\begin{array}{c}107.6 \\
2\end{array}$ \\
\hline Total & $\mathbf{8 8 5 , 9 9 8}$ & $1,001,623$ & 25.71 & $\begin{array}{c}\mathbf{2 2 5 . 7} \\
1\end{array}$ \\
\hline
\end{tabular}


Cost of Production and Addition of Capital Goods (Rp/Ha/Harvest:

\begin{tabular}{|l|c|c|c|c|}
\hline Cocoa & $3,569,917$ & $3,168,182$ & $(11.25)$ & 88.75 \\
\hline Coconut & $3,747,500$ & $3,475,000$ & $(7.27)$ & 92.73 \\
\hline Clove & $2,805,263$ & $2,522,368$ & $(10.08)$ & 89.92 \\
\hline Total & $\mathbf{1 0 , 1 2 2 , 6 8 1}$ & $\mathbf{9 , 1 6 5 , 5 5 0}$ & $\mathbf{( 2 8 . 6 1 )}$ & $\begin{array}{c}\mathbf{2 7 1 . 3} \\
\mathbf{9}\end{array}$ \\
\hline Average & $\mathbf{2 , 2 0 1 , 7 3 6}$ & $\mathbf{2 , 0 3 3 , 4 3 5}$ & $\mathbf{( 0 . 5 8 )}$ & $\mathbf{9 9 . 4 2}$ \\
\hline
\end{tabular}

Total Consumption and Cost of Production and Addition of Capital Goods

\begin{tabular}{|l|c|c|c|c|}
\hline Cocoa & $4,455,915$ & $4,169,805$ & $(6.42)$ & 93.58 \\
\hline Coconut & $4,633,498$ & $4,476,623$ & $(3.39)$ & 96.61 \\
\hline Clove & $3,691,261$ & $3,523,991$ & $(4.53)$ & 95.47 \\
\hline Total & $12,780,675$ & $12,170,419$ & $(14.34)$ & 6 \\
\hline Average & $\begin{array}{c}4,260,224.8 \\
4\end{array}$ & $\begin{array}{c}4,056,806.4 \\
1\end{array}$ & $(4.78)$ & $\mathbf{9 5 . 2 2}$ \\
\hline
\end{tabular}

Table 3 shows that the average price index paid by farmers in subsectors of plantation crops is $28.61 \%$ or IHB 271.39\%. This means that there will be a decrease in farming costs in 2020 in North Kolaka Regency.

\section{NTP Developments}

The exchange rate of farmers plantation can not be separated from some of its constituents, both the constituent components ht (price received) and the constituent components HB (price paid), and several factors that affect the exchange rate of plantation farmers will be very useful for the improvement of policy and plantation development programs in the future. NTP conception measures the exchange rate of agricultural commodities produced by farmers to products purchased by farmers for consumption purposes and purposes in producing farming. The exchange rate of farmers of food crops and farms (NTPP and NTPT) is defined as the ratio between the price received by farmers (HT) and the price paid by farmers $(\mathrm{HB})$ or NTP $=$ HT/HB.

Farmer Exchange Rate (NTP) is a comparison figure between the price index received by farmers and the price index paid by farmers expressed in percentage. While the price index received by farmers shows the development of the price of agricultural goods/products produced by farmers. The price index paid by farmers shows the development of the price of goods needed by farmers for both consumption and production. By comparing the two price developments in one parameter /measure, namely NTP, it can be known whether the increase in spending for farmers' needs can be compensated by the increase in farmers' income from their production. Or vice versa whether the increase in harvest prices can increase the income of farmers which in turn improves the welfare of farmers. An overview of NTP in North Kolaka Regency is presented in Table 4.

The results of the analysis showed that the exchange rate of farmers in the subsector of cocoa communiqué plantation crops obtained a value of 114.05 ; 93.58; 121.88. This means that the NTP value is greater than 100 (NTP > 100), as well as coconut and cloves with an average amount of 110.23 ; 95,22; and 115.81. This gives the meaning that farmers suffer losses. The increase in the price of production goods is relatively greater than the increase in the price of consumer goods and production costs. Farmers' expenditures increased more than their income, so the level of welfare is less good than the level of welfare of farmers in the previous period. In addition, the figure also gives the meaning that the value issued by farmers is greater than the value received by farmers. Farmers suffer losses in farming so they are not able to meet the needs of family life.

Table 4. Average Exchange Rate of Farmers in Subsectors of Plantation Crops in North Kolaka District in 2019-2020.

\begin{tabular}{|l|c|c|c|}
\hline $\begin{array}{c}\text { Plantation } \\
\text { Plants }\end{array}$ & IHP (\%) & IHB (\%) & NTP (\%) \\
\hline Cocoa & 114.05 & 93.58 & 121.88 \\
\hline Coconut & 110.38 & 96.61 & 114.25 \\
\hline Clove & 106.27 & 95.47 & 111.31 \\
\hline
\end{tabular}




\begin{tabular}{|l|c|c|c|} 
Total & 330.70 & 285.66 & 347.44 \\
\hline Average & 110.23 & 95.22 & 115.81 \\
\hline
\end{tabular}

\section{IV.CONCLUSION}

Based on the results of the research and discussion in this study, it was concluded that the exchange rate of farmers in the subsector of plantation crops obtained an average value of 115.81 .

\section{REFERENCES}

[1]. I. Suhendra, "Exchange Rate, Economic Openness And Economic Growth Performance in Indonesia," Tirtayasa Journal of Business Research and Management, 4(1), Pp 78-93, 2020.

[2]. L. Saleh, "Analysis of Exchange Rate and Household Expenditure of Rice Paddy Farmers in Konawe Regency," Surya Agritama: Journal of Agricultural And Livestock Sciences, 9(2), Pp. 126-129, 2020.

[3]. I. G. A. D. Pramesti, N. N. S. Ekayani, And L. G. P. S. E. Jayanti, "Effect of Rupiah Exchange Rate Movement on USD, Interest Rate, and Inflation on The Share Price of Mining Companies Listed on the Indonesia Stock Exchange,"Warmadewa Accounting Research Journal, 1(2), Pp. 54-62, 2020.

[4]. M. S. Pradana, D. Rahmalia, And E. D. A. Prahastini, "Forecasting The Exchange Rate of Farmers Lamongan With Arima," Mathematics Journal, 10 (2), Pp. 91-104, 2020.

[5]. M. Pangestika And T. M. Prihtanti, "Farmer Exchange Rate Comparison (NTP) Between Agricultural Subsectors in Indonesia," Agrisaintifika: Journal of Agricultural Sciences, 4(1), Pp. 30-36, 2020.

[6]. F. O. Anpersya And W. Wirdanengsih, "Planting Educational Values In Farming Families Who Have Children Drop Out of Junior High School
In Jorong Iv Rattan Sap," Jurnal Perspektif, 3(3), Pp. 528-534, 2020.

[7]. G. B. Andhika, I. W. Sumarjaya, And I. G. A. M. Srinadi, "Farmer Exchange Rate Forecasting Using Singular Spectrum Analysis Method," EMathematics Journal, 9(3), Pp. 171-176, 2020.

[8]. S. Y. Amalutfia And M. Hafiyusholeh, "Analysis of Rupiah Exchange Rate Forecast against Dollar And Yuan Using Fts-Markov Chain,” Vygotsky: Journal of Mathematics Education, 2(2), Pp. 102113, 2020.

[9]. E. Adriani, H. Hasminidiarty, And A. Fahmi, "Farmer Exchange Rate And Household Consumption Pattern (Case Study: Farmers Of Food Crops And Horticulture In East Sabak District of Tanjung Jabung Timur Regency)," JMas (Journal of Management And Science), 5(1), Pp. 77-87, 2020.

[10].M. Taufiq And N. A. Natasah, "Analysis of The Influence of Exchange Rates on Exports of Indonesia's Leading Commodities," Journal of Economic Dynamics of Development, 2(1), Pp. 141-146, 2019.

[11].S. P. Siregar, D. Hartama, And A. Wanto, "Estimated Exchange Rate of Farmers Subsector of Food Crops Using JST In North Sumatra Province," Proceedings of National Seminar on Information Science Research (Senaris), Pp 369377, 2019.

[12].R. A. P. Setiawan, T. I. Noor, L. Sulistyowati, And I. Setiawan, "Analysis of Soybean Farmers' Welfare Level Using Farmer Exchange Rate Approach (NTP) And Farmer Household Income Exchange Rate (NTPRP),"Integrated Agribusiness Journal, 12(2), Pp. 178-189, 2019.

[13].E. D. Satriana, Harianto, And D. S. Priyarsono, "Effect of Exchange Rate Volatility on Indonesia's Main Agricultural Export Performance,"Buletin Ilmiah Litbang Perdagangan, 13(2), Pp. 163-186, 2019.

[14].R. Prasetyo And R. N. A. Saksono, "Effect of Input Subsidy on Rice Farmers Exchange Rate in 
Indonesia," Jurnal Good Governance, 15(2), Pp. 193-210, 2019.

[15].J. C. Pelengkahu, O. E. H. Laoh, And P. A. Pangemanan, "Exchange Rate of Rice Paddy Farmers In Tompaso Baru Subdistrict Minahasa Regency," Agri-Sosioekonomi, 15(1), Pp. 9-16 2019.

[16].P. N. Sari, Y. S. Hilmi, And W. S. Hariswanti, "Feasibility And Exchange Rate of Organic Rice Farmers In Sleman Regency," Agriekonomika, 7(2), Pp. 120-128, 2018.

[17].M. Patiung, "Farmer Exchange Rate Analysis of Jombang Regency 2018," Scientific Journal of Socio Agribusiness, 18(2), Pp. 1-18, 2018.

[18].C. Muslim, "Plantation Commodity Farmers Exchange Rate," Sepa: Journal of Socio-Economic Agriculture and Agribusiness, 13(2), Pp. 142-158, 2018.

[19].C. M. Keumala And Z. Zainuddin, "Farmer Welfare Indicators Through Farmer Exchange Rate (NTP) And Sharia Financing as a Solution," Economica: Journal of Islamic Economics, 9(1), Pp. 129-149, 2018.

[20].E. Akhmad, "Bali Provincial Farmers Exchange Rate 2015-2017,'Journal Of Agribusiness Management, 6(1), Pp. 41-54, 2018.

[21].M. Patiung, "Preparation of Farmers Exchange Rate Bondowoso Year 2017," Scientific Journal of Socio Agribusiness, 17(2), Pp. 1-23, 2017.

[22].M. Patiung, "Preparation of Farmers Exchange Rate Jombang District in 2016," Scientific Journal of Socio Agribusiness, 16(1), Pp. 24-46, 2016.

[23].D. Aulia And S. F. Ayu, "Analysis of Interrelated Between Farmers Exchange Rate And Life Expectancy In North Sumatra," Andalas Public Health Journal, 10(2), Pp. 116-122, 2017.

[24].T. Nurasa And M. Rachmat, "Exchange Rate of Rice Farmers In Several Rice Production Centers In Indonesia," Journal of Agro Economics, 31(2), Pp. 161-179, 2016.

[25].B. Hutabarat, "Measurement of The Impact of Exchange Rate on Rice Farmers' Production and
Income," Journal of Agro Economics, 15(2), Pp. 21-35, 2016.

[26].P. U. Hadi, "Study of Agricultural Commodity Exchange Rate Policy," Agro Economic Research Forum, 2(1), Pp. 20-31, 2016.

\section{Cite this article as :}

Salahudin, Laode Muh. Munadi, Muhammad Amrullah Pagala, Rina Astarika, "Exchange Rate Behavior of Plantation Subsector Farmers in North Kolaka Regency", International Journal of Scientific Research in Science, Engineering and Technology (IJSRSET), Online ISSN : 2394-4099, Print ISSN : 2395-1990, Volume 8 Issue 4, pp. 90-97, July-August 2021.

Available at

doi : https://doi.org/10.32628/IJSRSET218423

Journal URL : https://ijsrset.com/IJSRSET218423 